\title{
Surface bacterial community, fatty acid profile, and antifouling activity of two congeneric sponges from Hong Kong and the Bahamas
}

\author{
On On Lee ${ }^{1}$, Lai Hung Yang ${ }^{1}$, Xiancui Li $^{1}{ }^{1}$ Joseph R. Pawlik ${ }^{2}$, Pei-Yuan Qian ${ }^{1, *}$ \\ ${ }^{1}$ Coastal Marine Laboratory, Hong Kong University of Science and Technology, Clear Water Bay, Hong Kong, SAR \\ ${ }^{2}$ Department of Biology and Marine Biology, University of North Carolina at Wilmington, North Carolina, USA
}

\begin{abstract}
Bacterial communities on the surfaces of 2 congeneric sponges, Mycale adhaerens from Hong Kong and M. laxissima from the Bahamas, were compared using conventional cultivation techniques and terminal restriction fragment length polymorphism (TRFLP) analysis - a cultureindependent DNA fingerprinting technique. The bacterial community on the Hong Kong sponge was more diverse, in terms of the number and type of species isolated, and different from that on the Bahamas sponge, as evident from distinct clusters formed in TRFLP analysis. Distinctive bacterial types (i.e. TRFs) were commonly found on both sponge surfaces, but none of their bacterial isolates were common. At tissue level concentration, extract of the Hong Kong sponge inhibited the growth of a wide range of bacteria isolated from the Hong Kong reference surface, but did not affect any of those isolated from the Bahamas reference surface, indicating highly specific antibacterial activity. Extracts of both sponges, when incorporated into hydrogels and exposed to the natural environment for bacterial film development, dramatically altered the bacterial community in the films, either by shifting the bacterial composition or decreasing bacterial density. Settlement assays of the resulting films using larvae of the polychaete Hydroides elegans showed that the filmed hydrogels with Hong Kong sponge extracts either inhibited larval settlement or were toxic to the larvae; however, those with the Bahamas sponge extracts had no observable effect. HPLC (high performance liquid chromatography) and GC-MS (gas chromatography-mass spectrometry) analyses revealed different chemical profiles in the extracts; the Hong Kong sponge had a more diverse fatty acid profile. Our results suggest that the 2 congeneric sponges from geographically separated regions have 'speciesspecific', surface-associated bacterial communities and antifouling activities, which might be due to the differences in the chemical and fatty acid compositions of the 2 sponges. Alternately, different sponge-associated bacterial communities may reflect habitat differences in sympatric bacterial and fouling communities.
\end{abstract}

KEY WORDS: Congeneric sponges · Surface bacterial community · Mycale spp. • Antifouling · TRFLP · Fatty acid composition

\section{INTRODUCTION}

Marine sponges (Phylum: Porifera) are evolutionarily ancient metazoans and are well-known for their unique and diverse production metabolites showing various bioactivities (McClintock \& Baker 2001, Paul et al. 2006). Numerous studies show potent antifeeding (Furrow et al. 2003), allelopathic (Engel \& Pawlik
2000), antifungal (Tsukamoto et al. 1998), antibacterial (Thakur et al. 2004), anti-microfouling (Amsler et al. 2000), or anti-macrofouling (Kubanek et al. 2002) activities in different species of marine sponges. There is growing evidence that some of these bioactive metabolites are of microbial origin (Kon-ya et al. 1995), given the fact that sponges harbor a remarkable array of microorganisms, for instance, bacteria (Hentschel et 
al. 2001), cyanobacteria (Thacker \& Starnes 2003), and fungi (Maldonado et al. 2005), both internally and on their surfaces. Through evolution, sponges may have developed a symbiotic relationship with certain kinds of microbes. Therefore, study of the microbial community associated with sponges is important for understanding sponge-microbe symbiosis, as well as the bioactivity displayed by sponges.

Different sponges from different locations and sponges of the same species collected at different times or of the same genus collected at the same location may possess highly consistent associations with certain kinds of bacteria (Margot et al. 2002, Lafi et al. 2005). These associated bacteria may co-evolve with sponges, forming stable, specific, and, perhaps, symbiotic interrelationships with their hosts (Hentschel et al. 2002). In contrast, 2 congeneric sponges Callyspongia spp. from different biogeographic regions have different bacterial associates (Qian et al. 2006). Therefore, it remains far from conclusive whether differences in sponge-associated bacterial communities can hold for other congeneric sponges from geographically separated locations a fact which could provide useful information on the co-evolution of bacteria and sponges.

Similar to the sponge-microbe association, bioactive compounds isolated from sponges may have evolved together with the associated microbes or in response to sympatric predators, competitors, or fouling organisms (McClintock \& Baker 1997). Therefore, it is of great scientific interest to know if congeneric sponges from different locations produce similar metabolites or show similar bioactivity. In fact, there have been several studies attempting to answer this question, but their findings varied substantially. For instance, McClintock \& Baker (1997) pointed out that the Antarctic congeners of Haliclona produced different types of secondary metabolites when compared with their tropical counterparts; in contrast, the Antarctic Latrunculia and Dendrilla produced similar chemicals in temperate and tropical congeners. Although Becerro et al. (2003) has recently suggested that chemical defenses against predators in tropical and temperate congeneric sponges are equally strong, there has been no study that compares the antifouling activity in congeneric sponges from tropical and sub-tropical regions.

The unique ability of sponges to adapt to any ecosystem can be due to the structural features of their membranes (Rod'kina 2005). The main components of sponge membranes, phospholipids, consist of unusual, long-chained fatty acids (Ando et al. 1998). Many unusual fatty acids isolated from sponges have potent cytotoxic (Tachibana et al. 1981), antimicrobial (Carballeira et al. 2002), and antifungal (Fusetani et al. 1993) activities. In addition, some branched fatty acids, particularly those with iso, anteiso, cyclopropyl, and monomethyl groups, are suggested to be of bacterial origin and specific to particular bacteria; because of this, they can be used as biological markers for bacterial associates in sponges (Gillian et al. 1988). Therefore, the study of fatty acid profiles in sponges may help understand the bacterial association, as well as the bioactivity, of sponges. However, the relationships of these 3 aspects in congeneric sponges have not been examined so far.

In the present study, we compared: (1) the surfaceassociated bacterial communities of the 2 congeneric sponges using a DNA fingerprinting technique, (2) the antifouling activity of the crude sponge extracts in 2 assays (inhibition of bacterial growth and attachment and inhibition of larval settlement of a major fouling polychaete Hydroides elegans in Hong Kong waters), and (3) the chemical and fatty acid compositions of the crude sponge extracts. We selected Mycale adhaerens from Hong Kong in the sub-tropical area and M. laxissima from the Bahamas in the tropical area for comparison. The genus Mycale was established in 1867 (Gray 1867), and there are $>250$ species in this genus at the time of writing. $M$. adhaerens Lambe was firstly discovered on the Pacific Coast of Canada and in the Bering Sea (Lambe 1893), can now be found in the San Juan Archipelago, Sea of Japan, and Greenland Sea, and is frequently associated with scallops. The surfaceassociated bacterial community and antifouling activity of this sponge have been recently studied by Qian's research group (Lee \& Qian 2003, 2004, Lee et al. 2006), and its cytotoxic activity has been documented by Fusetani et al. (1991). On the other hand, M. laxissima Duhassaing \& Michelotti are found in the Caribbean Sea (Duhassaing \& Michelotti 1864) and along the Brazilian coastline; it is usually associated with hydrozoa and seaweed. So far, there have only been 2 studies on the cytotoxic and neurotoxic activities displayed by this sponge (Rangel et al. 2001, Freitas et al. 2003), but antifouling activity was not studied or compared.

\section{MATERIALS AND METHODS}

Collection of sponge tissues and bacteria. Tissue of the sponge Mycale adhaerens was obtained at a depth of $3 \mathrm{~m}$ from a fish farm in Long Harbour, Hong Kong $\left(22^{\circ} 27^{\prime} \mathrm{N}, 114^{\circ} 21^{\prime} \mathrm{E}\right)$ in April 2003, while that of the sponge $M$. laxissima was obtained at a depth of about $5 \mathrm{~m}$ from Great Stirrup Cay, Bahaman Islands $\left(25^{\circ} 51^{\prime} \mathrm{N}, 77^{\circ} 52^{\prime} \mathrm{W}\right)$ in July 2003 . Sponges were carefully brought to the water surface and flushed with autoclaved $0.22 \mu \mathrm{m}$ filtered seawater (AFSW) to remove loosely attached bacteria. Eight colonies of each sponge species, each with a surface area of 
ca. $40 \mathrm{~cm}^{2}$, were swabbed with sterile cotton tips to collect epibiotic bacteria; 4 of them were individually suspended in $1 \mathrm{ml}$ of AFSW in $1.5 \mathrm{ml}$ Eppendorf tubes for the isolation of epibiotic bacteria, while the other 4 were individually frozen in $0.8 \mathrm{ml}$ of extraction buffer (100 mM of Tris- $\mathrm{HCl}, 100 \mathrm{mM}$ of $\mathrm{Na}_{2}$-EDTA, $100 \mathrm{mM}$ of $\mathrm{Na}_{2} \mathrm{HPO}_{4}, 1.5 \mathrm{M}$ of $\mathrm{NaCl}, 1 \%$ of $\mathrm{CTAB}$; at $\mathrm{pH}$ 8) for DNA fingerprinting analysis of bacterial communities. Reference bacterial communities were collected analogously from the surfaces of a polystyrene Petri dish (Falcon No. 1006) deployed in the close vicinity of the sponges for $7 \mathrm{~d}$. For the chemical extraction of sponge tissue, colonies of approximately $550 \mathrm{ml}$ of $M$. adhaerens and $440 \mathrm{ml}$ of $M$. laxissima (determined by water displacement) were sealed in sterile plastic bags and transported back to the laboratory.

Isolation and identification of epibiotic bacteria. Isolation and identification of bacteria from the sponge and reference surfaces followed Lee \& Qian (2003). Briefly, bacterial suspensions, after diluting with AFSW to 10- and 100-fold, were spread on nutrient agar $(0.3 \%$ yeast extract, $0.5 \%$ peptone, $1.5 \%$ agar in AFSW) and incubated at $28^{\circ} \mathrm{C}$ under a $15 \mathrm{~h}$ light:9 h dark photoperiod for $48 \mathrm{~h}$. After incubation, morphologically distinct colonies were isolated and identified by comparative analysis of $16 \mathrm{~S}$ rRNA gene sequences. The primers used were $355 \mathrm{~F}$ and $1055 \mathrm{R}$, and the PCR (polymerase chain reaction) conditions were the same as described in Lee \& Qian (2003). Sequences from individual primers were assembled using the Sequencher software package (Gene Codes), and the assembled nucleotide sequences were compared with those deposited in GenBank (www.ncbi.nlm.nih.gov) to obtain the closest match.

DNA fingerprinting analysis of bacterial communities. The extraction and purification of total bacterial DNA from the samples followed the SDS (sodium dodecyl sulfate)-based method described in Liu et al. (1997). For the analysis of bacterial communities by terminal restriction fragment length polymorphism (TRFLP) analysis, the 16S rRNA genes in DNA extracts were amplified by PCR using the primers $341 \mathrm{~F}$ and 926R-Fam, following the conditions stated in Lee \& Qian (2004). PCR products were cleaved with $10 \mathrm{U}$ of the restriction enzyme $\mathrm{MspI}$ at $37^{\circ} \mathrm{C}$ for $6 \mathrm{~h}$, followed by purification with the Wizard $^{\circledR}$ PCR preps DNA purification system (Promega) according to the manufacturer's protocol. Then, $10 \mu \mathrm{l}$ of purified products mixed with $0.5 \mu \mathrm{l}$ of internal size standard (ET-550R, Amersham) was denatured at $95^{\circ} \mathrm{C}$ for 2 min, snap cooled on ice, and analyzed by electrophoresis on a MegaBACE genetic analyzer (Amersham) operated in the genotyping mode. After electrophoresis, the size of the fluorescently labeled terminal restriction fragments (TRFs) was determined by comparison with the internal standard using the software Fragment Profiler (Amersham).

Extraction of sponge tissue. Sponge tissues for chemical extraction were blot dried, cut into small pieces, and extracted twice in equal volumes of a 1:1 mixture of methanol/chloroform $\left(\mathrm{MeOH} / \mathrm{CHCl}_{3}\right)$ for $12 \mathrm{~h}$ each, with gentle agitation. After extraction, sponge tissue was removed from the solvents by centrifugation. Then, the organic extract was separated into 2 layers $\left(\mathrm{MeOH}\right.$ and $\mathrm{CHCl}_{3}$ ) in a separation funnel, and each layer was dried by rotary evaporation. The dry $\mathrm{MeOH}$ and $\mathrm{CHCl}_{3}$ extracts were re-dissolved in one-tenth volume of the original sponge tissue of autoclaved double-distilled water $\left(\mathrm{ddH}_{2} \mathrm{O}\right)$ and $\mathrm{CHCl}_{3}$, respectively, generating extracts at $10 \times$ tissue-level concentration (TLC). TLC is measured on a volumetric basis assuming that compounds extracted from a specimen are homogenous distributed over the whole tissue volume. Without knowing the actual distribution of compounds in tissues, TLC is more relevant and acceptable measurement in ecological studies. In total, 14.3 and $10.4 \mathrm{~g}$ (dry weight) of $\mathrm{MeOH}$ extracts and 10.1 and $4.6 \mathrm{~g}$ of $\mathrm{CHCl}_{3}$ extracts were obtained from $550 \mathrm{ml}$ of Mycale adhaerens and $440 \mathrm{ml}$ of M. laxissima, respectively.

Disc-diffusion assays. Antibacterial growth activity of the sponge tissue extracts were assessed using discdiffusion assays. Bacterial isolates from the reference surfaces were grown to the stationary phase in nutrient broth. Then, $200 \mu \mathrm{l}$ volumes of these cultures were individually spread on nutrient agars. The sponge tissue extracts were diluted to $1 \times$ TLC with corresponding solvents. Sterile paper discs $(6.5 \mathrm{~mm}$ diameter, Whatman No. 1), each loaded with $20 \mu$ l of the extracts (equivalent to the volume of a paper disc) were subsequently placed onto the inoculated agar, with replications $(\mathrm{n}=2)$. Pure solvents and streptomycin $(50 \mu \mathrm{g}$ $\operatorname{disc}^{-1}$ ) served as controls. After $24 \mathrm{~h}$ of incubation at $28^{\circ} \mathrm{C}$, the width of the growth inhibition zone measured from the edge of the paper disc to the unaffected bacterial lawn was recorded.

Phytagel assays. Antibacterial attachment activity of sponge tissue extracts were assessed using phytagel assays as described in Harder et al. (2004) with slight modifications. Briefly, $3 \mathrm{ml}$ of aliquots of $\mathrm{MeOH}$ or $\mathrm{CHCl}_{3}$ extract at $20 \times$ TLC was transferred to individual $50 \mathrm{ml}$ sterile polypropylene tubes (Falcon 2096), each of which contained $27 \mathrm{ml}$ of $4 \%$ (w/v) hydrogel (Phytagel, Sigma Chemical) solution prepared in hot $\mathrm{ddH}_{2} \mathrm{O}\left(\right.$ ca. $70^{\circ} \mathrm{C}$ ). After cooling to room temperature to yield transparent gel cylinders containing extracts at a final concentration of $2 \times$ TLC and keeping overnight at $4^{\circ} \mathrm{C}$, the gel cylinders were sliced into $5 \mathrm{~mm}$ thick gel discs (volume of each disc is approximately $2.5 \mathrm{ml}$ ) using sterile razor blades. Crude extract at a final 
extract concentration of $2 \times$ TLC was used, in considering the diffusion rate of compounds from the gel discs, to ensure compounds are present throughout the assays. Positive control gel discs were prepared accordingly using a concentrated antibiotic solution, which yielded a final concentration of $219 \mathrm{mg} \mathrm{l}^{-1}$ penicillin $+365 \mathrm{mg} \mathrm{l}^{-1}$ streptomycin in the gel cylinder, and negative control gel discs were made with pure $\mathrm{ddH}_{2} \mathrm{O}$ or $\mathrm{CHCl}_{3}$ accordingly. Twenty replicates were prepared for each treatment.

Gel discs were pierced with fishing line and anchored $2 \mathrm{~m}$ below the water surface at the pier of the Hong Kong University of Science and Technology. After $72 \mathrm{~h}$ exposure to natural flowing seawater, the gel discs were retrieved and rinsed with AFSW; 12 of which (4 replicates) were subject to extraction of bacterial community DNA and TRFLP analysis as mentioned above, 5 were directly used for larval settlement bioassays as follows, and the remaining 3 were fixed with $4 \%$ formaldehyde, stained with DNA-binding fluorochrome 4,6-diamidino-2-phenylindole (DAPI) at a concentration of $0.5 \mu \mathrm{g} \mathrm{ml}^{-1}$ for $10 \mathrm{~min}$, and visualized at $1000 \times$ magnification in 10 randomly chosen fields of view under an epifluorescent microscope to determine the bacterial cell density.

Larval settlement bioassays. Larvae of Hydroides elegans were obtained and raised according to Lee \& Qian (2003). Five gel discs directly retrieved from the field (i.e. coated with natural biofilms) were placed in polystyrene Petri dishes (Falcon No. 1006) and covered with $7 \mathrm{ml}$ of AFSW. To investigate the effect of biofilms on larval settlement, 20 competent larvae were added to each Petri dish that contained a biofilm-coated gel discs. After $24 \mathrm{~h}$ of incubation at $24^{\circ} \mathrm{C}$ on a $15 \mathrm{~h}$ light: $9 \mathrm{~h}$ dark photoperiod, the percentage of larvae that had undergone settlement was determined by counting the number of individuals that had adhered to the gel surface and produce calcified tubes and tentacles. Additionally, percent survivorship in each treatment was scored as the sum of settled and free-swimming larvae. Bioassays to investigate the potential larval settlement inhibition of sponge extracts in gel discs followed the same procedures, except that gel discs with prior exposure to seawater but with the biofilms being removed using cotton tips for TRFLP analysis were placed in individual wells and that each well received 20 larvae that had been exposed to $10^{-4} \mathrm{M}$ IBMX (3-isobutyl-1-methylxanthine) $30 \mathrm{~min}$ prior to the bioassays. IBMX is a pharmacological compound that can effectively induce larval settlement of $H$. elegans.

Determination of chemical profile and fatty acid composition of sponge extracts. Crude $\mathrm{MeOH}$ and $\mathrm{CHCl}_{3}$ extracts of Mycale adhaerens and M. laxissima at $20 \times$ TLC were analyzed using the reverse phase HPLC (Lichrospher 100 RP C18 EC 5, $250 \times 4$ mm i.d.; gradient $5 \%$ aqueous $\mathrm{CH}_{3} \mathrm{CN}$ to $85 \% \mathrm{CH}_{3} \mathrm{CN}$ ) at a

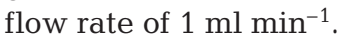

Crude $\mathrm{CHCl}_{3}$ extracts of the 2 sponges at $1 \times$ TLC and methyl esters of fatty acids (MEFAs) of total lipids in the extracts were analyzed using coupled gas chromatography-mass spectrometry (GC-MS). Total lipids were obtained by dissolving the extracts in $\mathrm{CHCl}_{3}$ : $\mathrm{CH}_{3} \mathrm{OH}: \mathrm{ddH}_{2} \mathrm{O}$ (1:1:0.9). After phase separation at $4^{\circ} \mathrm{C}$, the organic phase was collected and evaporated to dryness in vacuo. Fatty acids in the crude lipid samples (5 mg) were transmethylated according to Carreau \& Dubacq (1978) and then dissolved in $0.5 \mathrm{ml}$ of $\mathrm{ddH}_{2} \mathrm{O}$. MEFAs were extracted with $2 \mathrm{ml}$ of hexane 3 times, and the organic phase was combined and evaporated to dryness in vacuo. MEFAs were purified by thin layer chromatography using benzene as solvent and analyzed by GC-MS. GC was performed on relatively nonpolar capillary columns (CP-Sil 8 CB-MS, 30 m length, $0.25 \mu \mathrm{m}$ film thickness, $0.25 \mathrm{~mm}$ i.d.; Varian 3800). For the crude extracts, temperature gradients used were initially from 65 to $120^{\circ} \mathrm{C}$ at $10^{\circ} \mathrm{C} \mathrm{min}^{-1}$ and then 120 to $310^{\circ} \mathrm{C}$ at $12^{\circ} \mathrm{C} \mathrm{min}^{-1}$, with subsequent constant temperature at $310^{\circ} \mathrm{C}$ for $10 \mathrm{~min}$. For MEFAs of the 2 extracts, temperature gradients used were initially from 180 to $220^{\circ} \mathrm{C}$ at $3^{\circ} \mathrm{C} \mathrm{min}{ }^{-1}$ and then 220 to $260^{\circ} \mathrm{C}$ at $2{ }^{\circ} \mathrm{C} \mathrm{min}{ }^{-1}$, with subsequent constant temperature at $260^{\circ} \mathrm{C}$ for $5 \mathrm{~min}$. Helium served as the carrier gas. MS was obtained by electron impact ionization at $70 \mathrm{eV}$ (Saturn 200 ion-trap). Each peak shown in a chromatogram represents an individual compound/ fatty acid in the extracts and was identified by comparison with the NIST GC-MS library and authentic standards of 15:0, 16:0, and 18:0.

Statistical analysis. For TRFLP analysis, TRFs that were $<50$ fluorescence units in intensity, $<35 \mathrm{bp}$ in size, or $>500$ bp in size were excluded from statistical analysis, in order to screen off background noise, to avoid pseudo-TRFs derived from primers, and to avoid inaccurate size determination, respectively. TRFLP profiles were analyzed using multivariate techniques. The Bray-Curtis coefficient was calculated based on the total number of TRFs in all samples and the presence or absence of these TRFs in individual samples to produce similarity matrices. Due to differential amplification of DNA during PCR, the signal intensity of TRFs may not be an accurate reflection of the actual abundance of the corresponding bacterial types and, thus, was not considered in the analysis. Similarity matrices were utilized for agglomerative hierarchical clustering, using the PRIMER program (Plymouth Routines In Multivariate Ecological Research; Clarke \& Warwick 1994) to create dendrograms showing the similarity among samples. For the larval settlement bioassays, data in the form of percentages of larval survivorship and settlement were arcsine-transformed before statis- 
tical analysis. Normality of data was checked with Shapiro-Wilk's test, and homogeneity of variance within samples was analyzed by Cochran's test. Data that met the assumptions of parametric tests were analyzed using Student's $t$-test, while data that did not meet the assumptions of parametric analysis were analyzed by Mann-Whitney $U$-test.

\section{RESULTS}

\section{Isolation and identification of epibiotic bacteria}

Altogether 20 and 11 morphologically distinct bacteria were isolated from the surfaces of Mycale adhaerens and M. laxissima, respectively (these bacteria are referred to as 'HK sponge isolates' and 'Bahamas sponge isolates', respectively, hereafter). Comparative sequence analysis of the $16 \mathrm{~S}$ rRNA gene revealed that $11 \mathrm{HK}$ sponge isolates belonged to the $\gamma$-subdivision of Proteobacteria, 3 to the $\alpha$-subdivision of Proteobacteria, 5 to the division of Grampositive, and 1 to the Cytophaga-Flexibacter-Bacteroidetes division (Table 1, present study; Lee \& Qian 2003). Of the 11 Bahamas sponge isolates, 4 belonged to the $\gamma$-subdivision of Proteobacteria, 5 to the $\alpha$-subdivision of Proteobacteria, and 2 to the division of Gram-positive (Table 1). On the other hand, 36 and 24 bacteria were isolated from the reference surfaces (i.e. polystyrene Petri dish deployed in the close vicinity of the sponges for $7 \mathrm{~d}$ ) in Hong Kong and the Bahamas, respectively (referred to as 'HK reference isolate' and 'Bahamas reference isolate' hereafter). Among the $36 \mathrm{HK}$ reference isolates, 24 belonged to the $\gamma$-subdivision of Proteobacteria, 2 to the $\alpha$-subdivision of Proteobacteria, 8 to the division of Grampositive, and 2 to the CytophagaFlexibacter-Bacteroidetes division (Table 2, present study; Lee \& Qian 2003). The Bahamas reference isolates could also be affiliated with the $\gamma$-subdivision of Proteobacteria (15 isolates), the $\alpha$-subdivision of Proteobacteria (3 isolates), the division of Gram-positive (3 isolates), and the Cytophaga-Flexibacter-Bacteroidetes division (3 isolates). Results indicated that no bacterium was found in common on surfaces of either the sponge or reference iso- lates. The culturable bacterial community on the surface of $M$. adhaerens was more diverse than that on $M$. laxissima, but less diverse than that on the reference surfaces from either location in terms of the total number of isolates and the number of genera affiliated.
Table 1. Mycale spp. Phylogenetic affiliations of bacteria isolated from surface of sponges from Hong Kong and the Bahamas. Bacteria were isolated from 4 different sponge colonies for each species. Isolates from $M$. adhaerens and $M$. laxissima were annotated with prefix ' $A$ ' and ' $L$ ', respectively. The 16S rRNA gene sequences of individual bacterial isolates were compared to the nucleotide sequences deposited in GenBank. Closest phylogenetic affiliation for each isolate is indicated by strain name, accession number, and similarity

\begin{tabular}{|c|c|c|c|}
\hline Isolate & Strain & $\begin{array}{c}\text { Accession } \\
\text { No. }\end{array}$ & $\begin{array}{c}\text { Similarity } \\
(\%)\end{array}$ \\
\hline \multicolumn{4}{|c|}{$\gamma$-Proteobacteria } \\
\hline \multicolumn{4}{|c|}{ M. adhaerens (Hong Kong) } \\
\hline A5 & Alteromonas alvinellae & AF288360 & 99 \\
\hline A10 & Alteromonas alvinellae & AF288360 & 98 \\
\hline A12 & Microbulbifer hydrolyticus & U58338 & 97 \\
\hline $\mathrm{A} 20$ & Pseudoalteromonas piscicida & AF297959 & 97 \\
\hline A6 & Pseudoalteromonas sp. S9 & AB013442 & 98 \\
\hline A13 & Shewanella algae & X81621 & 98 \\
\hline A1 & Vibrio nereis ATCC $25917 \mathrm{~T}$ & X74716 & 96 \\
\hline A2 & Vibrio halioticoli & AB000392 & 97 \\
\hline A9 & Vibrio furnissii ATCC 35016T & X76336 & 96 \\
\hline A11 & Vibrio fluvialis NCTC $11327 \mathrm{~T}$ & X76335 & 97 \\
\hline A14 & Vibrio sp. BV25Ex & AF319769 & 99 \\
\hline \multicolumn{4}{|c|}{ M. laxissima (Bahamas) } \\
\hline L2 & Microbulbifer cystodytense & AJ620879 & 100 \\
\hline L5 & Pelagiobacter variabilis & AB167354 & 98 \\
\hline L10 & Pelagiobacter variabilis & AB167354 & 99 \\
\hline L11 & Vibrio harveyi OVL 99-52331-A & AY264926 & 98 \\
\hline \multicolumn{4}{|c|}{$\alpha$-Proteobacteria } \\
\hline \multicolumn{4}{|c|}{ M. adhaerens (Hong Kong) } \\
\hline A7 & Alpha proteobacterium ISHR1 & AB013442 & 99 \\
\hline A8 & Uncultured Ruegeria Ctax-Med-2 & AF259604 & 98 \\
\hline A15 & Alpha proteobacterium MBIC1876 & AB026194 & 99 \\
\hline \multicolumn{4}{|c|}{ M. laxissima (Bahamas) } \\
\hline L4 & Pseudovibrio denitrificans DN34 & AY486423 & 99 \\
\hline L6 & Pseudovibrio denitrificans DN34 & AY486423 & 99 \\
\hline L7 & Pseudovibrio denitrificans DN34 & AY486423 & 99 \\
\hline L12 & Pseudovibrio denitrificans DN34 & AY486423 & 99 \\
\hline L3 & Ruegeria sp. AS-36 & AJ391197 & 98 \\
\hline \multicolumn{4}{|c|}{ Cytophaga-Flexibacter-Bacteroidetes } \\
\hline \multicolumn{4}{|c|}{ M. adhaerens (Hong Kong) } \\
\hline A3 & Tenacibaculum mesophilum MBIC1543 & AB032502 & 97 \\
\hline \multicolumn{4}{|c|}{ Gram-positive } \\
\hline \multicolumn{4}{|c|}{ M. adhaerens (Hong Kong) } \\
\hline A4 & Bacillus licheniformis strain B & AF276309 & 99 \\
\hline A17 & Kocuria rhizophila JPL-9 & AY030315 & 98 \\
\hline A16 & Micrococcus kristinae & X80749 & 99 \\
\hline A18 & Micrococcus sp. Wuba57 & AF336358 & 99 \\
\hline A19 & Staphylococcus cohnii & AB009936 & 99 \\
\hline \multicolumn{4}{|c|}{ M. laxissima (Bahamas) } \\
\hline L1 & Bacillus vietnamensis & AB099708 & 96 \\
\hline L8 & Janibacter brevis & AJ310085 & 99 \\
\hline
\end{tabular}




\section{TRFLP analysis of bacterial communities}

Bacterial communities from different types of surfaces (sponge and reference) displayed distinctive TRFs (Table 3). For instance, TRFs of 179, 310,315 , and $373 \mathrm{bp}$ were observed on 1 type of surface only: Mycale laxissima, M. adhaerens, the Hong Kong reference, and the Bahamas reference, respectively. A TRF of $247 \mathrm{bp}$ was found exclusively on the sponge surfaces from 2 geographically separated locations, but not on either of the reference surfaces, while TRFs of 248 and $302 \mathrm{bp}$ were found on both of the sponge surfaces regardless of their presence on the reference surfaces (Table 3). On the other hand, TRFs of 182, 300, and $314 \mathrm{bp}$ were observed exclusively on the reference surfaces from the 2 locations, but not on any of the sponge surfaces. The number of discernible TRFs derived from each of the sponge- and reference-surface bacterial communities ranged from 8 to 16 , with those from the Bahamas reference surfaces displaying the highest number of TRFs, while those from the sponge surfaces at the same location showed the lowest. Cluster analysis of TRF patterns indicated that replicated samples from each type of surfaces formed distinct clusters with $>60 \%$ similarity among replicates (Fig. 1). Samples from the surfaces of $M$. adhaerens and M. laxissima formed another cluster, which was distantly related to the cluster formed by the samples from the reference surfaces at the 2 locations (similarity 15\%; Fig. 1).

\section{Antibacterial growth activity of extracts from Mycale spp.}

All HK reference isolates, except 2 (009 and 011), and all Bahamas reference isolates, except 3 (479, 484, 491), were susceptible to the streptomycin control (50 $\mu \mathrm{g} \mathrm{disc}^{-1}$ ) (Table 4). Of the $36 \mathrm{HK}$ reference isolates, 18 (i.e. $50 \%$ ) were susceptible to the $\mathrm{CHCl}_{3}$ extract of Mycale adhaerens from Hong
Table 2. Phylogenetic affiliations of bacteria isolated from surface of polystyrene Petri dish deployed in close vicinity of the sponges for $7 \mathrm{~d}$ (reference) in Hong Kong and the Bahamas $(\mathrm{n}=4)$. The 16S rRNA gene sequences of individual bacterial isolates were compared to the nucleotide sequences deposited in GenBank. Closest phylogenetic affiliation for each isolate is indicated by strain name, accession number, and similarity

\begin{tabular}{cccc}
\hline Isolate & Closest phylogenetic affiliation & \\
\cline { 2 - 4 } & Strain & Accession & Similarity \\
& No. & $(\%)$
\end{tabular}

\section{$\gamma$-Proteobacteria}

Hong Kong reference

030 Alteromonas sp. KT0903

020 Endocytic bacterium Noc15

039 Gram-negative bacterium CKT1

AF235119

AF262741

040 Gram-negative bacterium CKT1

AB036070

003 Idiomarina loihiensis

026 Marine bacterium Tw-3

012 North Sea bacterium H7

014 Photobacterium phospheum

016 Photobacterium sp. KT0248

AB036070

AF288370

AY028198

AF069665

Z19107

AF235127

028 Pseudoalteromonas haloplanktis subsp. AF214730 Tetradonis

029 Pseudoalteromonas haloplanktis subsp. AF214730 Tetradonis

019 Pseudoalteromonas issachenkonii KMM3549

007 Pseudoalteromonas sp. AS-27

006 Pseudoatleromonas sp. UST991130-004

004 Shewanella sp. GIT-33

010 Vibrio harveyi M4

008 Vibrio rumoence

015 Vibrio splendidus B17

023 Vibrio sp. ED4

037 Vibrio sp. EN276

033 Vibrio sp. UST991130-040

034 Vibrio sp. UST991130-040

024 Vibrio scophthalmi

032 Vibrio splendidus B17

Bahamas reference

473 Alteromonas macleodii DSM 6062

AF316144

AJ391188

AF465392

AF249336

AY046956

AB013297

AY046955

AY035895

AB038023

AF465358

AF465358

U46579

AY046955

474 Alteromonas macleodii subsp. Fijiensi

AMY18228

AL414399

483 Alteromonas macleodii subsp. Fijiensi

501 Alteromonas macleodii subsp. Fijiensi

AJ414399

AJ414399

480 Alteromonas marina SW-47

484 Alteromonas marina SW-47

489 Alteromonas marina SW-47

507 Alteromonas marina SW-47

476 Alteromonas sp. UST020129-020

506 Alteromonas sp. UST010723-005

503 Marinobacter aquaeolei

493 Pelagiobacter variabilis

519 Pseudoalteromonas flavipulchra A

AF529060

AF529060

AF529060

AF529060

AY241417

AY241400

AJ000726

AB167354

F297958

AJ551143

516 Pseudoalteromonas sp. S9

U80834

\section{$\alpha$-Proteobacteria}

Hong Kong reference

035 Marine alpha proteobacterium AS-19 AJ391181

013 Uncultured marine eubacterium HstpL28 AF159650

Bahamas reference

479 Erythrobacter flavus SW-52

491 Erythrobacter flavus SW-52

500 Erythrobacter flavus SW-52

AF500005

AF500004

AF500005

(Table continued on facing page) 
Table 2 (continued)

\begin{tabular}{|c|c|c|c|}
\hline \multirow{2}{*}{ Isolate } & \multirow[t]{2}{*}{ Closect phylocenetic a } & \multirow{2}{*}{$\begin{array}{l}\text { filiation } \\
\text { Accession } \\
\text { No. }\end{array}$} & \multirow[b]{2}{*}{$\begin{array}{c}\text { Similarity } \\
(\%)\end{array}$} \\
\hline & & & \\
\hline \multicolumn{4}{|c|}{ Cytophaga-Flexibacter-Bacteroidetes } \\
\hline \multicolumn{4}{|c|}{ Hong Kong reference } \\
\hline 001 & Tenacibaculum mesophilum MBIC4357 & AB032504 & 98 \\
\hline 011 & Flavobacteirum salegens & M92279 & 97 \\
\hline \multicolumn{4}{|c|}{ Bahamas reference } \\
\hline 487 & Cytophaga sp. J18-M01 & AB017046 & 91 \\
\hline 492 & Fabibacter halotolerans & DQ080995 & 100 \\
\hline 499 & Roseivirga spongocola & DQ080996 & 100 \\
\hline \multicolumn{4}{|c|}{ Gram-positive } \\
\hline \multicolumn{4}{|c|}{ Hong Kong reference } \\
\hline 025 & Bacillus benzoevorans & AY043085 & 97 \\
\hline 009 & Bacillus clausii LMG19634 & AF329475 & 98 \\
\hline 017 & Bacillus sp. 171544 & AF071856 & 99 \\
\hline 022 & Bacillus sp. KL-152 & AY030333 & 96 \\
\hline 005 & Bacillus sp. OS-5 & AJ296095 & 97 \\
\hline 002 & Exiguobacterium acetylicum & D55730 & 97 \\
\hline 018 & Microbacterium esteraromaticum & Y17231 & 99 \\
\hline 031 & Planococcus citreus & AF237975 & 98 \\
\hline \multicolumn{4}{|c|}{ Bahamas reference } \\
\hline 481 & Micrococcus luteus & AJ409096 & 99 \\
\hline 496 & Bacillus hwajinpoensis & AF541966 & 97 \\
\hline 512 & Halobacillus karajiensis DSM 14948 & AJ486874 & 98 \\
\hline
\end{tabular}

$\sim 10^{5}$ cells $\mathrm{mm}^{-2}$, whereas the hydrogels incorporated with antibiotics had a significantly lower bacterial cell density of $10^{4}$ cells $\mathrm{mm}^{-2}$ when compared with the $\mathrm{ddH}_{2} \mathrm{O}$ control (Mann-Whitney $U$-test; $\mathrm{p}=0$; Fig. 2a). Bacterial density on hydrogels treated with $\mathrm{CHCl}_{3}$ extract of Mycale adhaerens was similar to that on the $\mathrm{ddH}_{2} \mathrm{O}$ control hydrogels (Mann-Whitney $U$-test; $\mathrm{p}=0.08$ ). In contrast, bacterial density on hydrogels treated with $\mathrm{MeOH}$ extract of M. adhaerens was $4 \times 10^{4}$ cells $\mathrm{mm}^{-2}$, which was significantly lower than in the $\mathrm{ddH}_{2} \mathrm{O}$ control (Mann-Whitney $U$ test; $\mathrm{p}=0$ ), whereas bacterial densities on hydrogels treated with extracts of M. laxissima ranged from $1.8 \times 10^{5}$ to $2.2 \times 10^{5}$ cells $\mathrm{mm}^{-2}$, which was significantly higher than in the $\mathrm{ddH}_{2} \mathrm{O}$ and $\mathrm{CHCl}_{3}$ controls (Mann-Whitney $U$-test; $\mathrm{p}=0)$.

Bacterial communities on the $\mathrm{ddH}_{2} \mathrm{O}$ and $\mathrm{CHCl}_{3}$ controls were highly similar, as indicated by the occurrence of 18 TRFs in common (Table 5) and $>60 \%$ similarity in the cluster

Kong, but none was affected by the $\mathrm{MeOH}$ extract of the sponge from the same location (Table 4). Similarly, no Bahamas reference isolate was susceptible to the $\mathrm{MeOH}$ extract of $M$. laxissima from the Bahamas, but weak inhibition by the $\mathrm{CHCl}_{3}$ extract of the sponge on the growth of 1 isolate from the same location was observed. When sponge extracts from one location were tested against the reference bacteria isolated from the other location, different levels of antibacterial growth activity were observed; $\mathrm{MeOH}$ and $\mathrm{CHCl}_{3}$ extracts of $M$. laxissima inhibited the growth of 7 (i.e. $19.4 \%$ ) and 5 (i.e. 13.9\%) of the HK reference isolates, respectively, while extracts from $M$. adhaerens did not affect the growth of any Bahamas reference isolates. When extracts from different sponges were tested against the growth of bacteria isolated from the sponge surfaces, only 1 epibiotic bacterium from $M$. adhaerens was susceptible (Table 4).

\section{Antibacterial attachment activity of extracts from Mycale spp.}

After $72 \mathrm{~h}$ of exposure to flow-through seawater in the natural environment, bacterial densities on the surfaces of hydrogels prepared with $\mathrm{ddH}_{2} \mathrm{O}$ alone and control hydrogels treated with $\mathrm{CHCl}_{3}$ alone were analysis (Fig. 3), whereas those on the antibiotic control were substantially different from the $\mathrm{ddH}_{2} \mathrm{O}$ and $\mathrm{CHCl}_{3}$ controls in terms of the length and average number of TRFs. Bacterial communities on the hydrogels incorporated with different extracts of Mycale adhaerens and M. laxissima generally displayed high dissimilarity among themselves, as well as compared to controls (Fig. 3, Table 5). Four TRFs (91, 129, 182, and $314 \mathrm{bp})$ were excluded from the bacterial communities developed on all different kinds of extract-incorporated hydrogels when compared with the $\mathrm{ddH}_{2} \mathrm{O}$ and $\mathrm{CHCl}_{3}$ controls, while some TRFs (e.g. 368, 370, and 422 bp) were absent from the bacterial communities developed on certain kinds of extract-incorporated hydrogels (Table 5). Several other TRFs (e.g. 42, 81, 127, and 301 bp) were found exclusively on the extract-incorporated hydrogels, but not on any of the $\mathrm{ddH}_{2} \mathrm{O}$ and $\mathrm{CHCl}_{3}$ controls (Table 5). Cluster analysis also indicated that the bacterial communities that developed on all different kinds of extract-containing hydrogels and on the antibiotic control differed substantially from those on the $\mathrm{ddH}_{2} \mathrm{O}$ and $\mathrm{CHCl}_{3}$ controls (Fig. 3). Bacterial communities on the hydrogels incorporated with extracts of $M$. adhaerens formed a cluster, which was distantly related to the cluster formed by the antibiotic control and the $\mathrm{CHCl}_{3}$ extract of $M$. laxissima. 
Table 3. Mycale spp. Terminal restriction fragments (TRF) observed in bacterial communities from surfaces of 4 ind. of sponges $M$. adhaerens (HKS) and M. laxissima (BS) in comparison to those from reference surfaces of Hong Kong (HKR) and the Bahamas (BR). Data are number of occurrences of a particular TRF among 4 replicates. No data: total absence of TRF in a sample

\begin{tabular}{|c|c|c|c|c|}
\hline $\begin{array}{l}\text { Length of } \\
\text { TRF (bp) }\end{array}$ & HKS & BS & HKR & BR \\
\hline 38 & & & & 4 \\
\hline 40 & & & & 3 \\
\hline 41,71 & & & & 4 \\
\hline 74 & & & & 2 \\
\hline 75 & & & & 4 \\
\hline 76 & & & & 3 \\
\hline 86 & & 4 & & \\
\hline 88 & & & 4 & \\
\hline 128 & & & 2 & \\
\hline 149 & 2 & & & \\
\hline 179,180 & & 4 & & \\
\hline 182 & & & 3 & 3 \\
\hline 216 & & & & 3 \\
\hline 247 & 3 & 4 & & \\
\hline 248 & 4 & 4 & & 4 \\
\hline 249 & 2 & & & \\
\hline 299 & & 4 & & \\
\hline 300 & & & 4 & 4 \\
\hline 301 & & 2 & 4 & 4 \\
\hline 302 & 2 & 2 & & 4 \\
\hline 308 & & 3 & & \\
\hline 309 & & 4 & & \\
\hline 310,311 & 4 & & & \\
\hline 312 & & & & 4 \\
\hline 314 & & & 4 & 3 \\
\hline 315 & & & 4 & \\
\hline 366 & & & 3 & \\
\hline 368 & & & 4 & \\
\hline 369 & 3 & & 2 & \\
\hline 370 & & & 4 & \\
\hline 371 & 3 & & & \\
\hline 372 & 2 & & & \\
\hline 373 & & & & 4 \\
\hline 374 & & & & 2 \\
\hline 375 & 3 & & 4 & \\
\hline 419,420 & 2 & & & \\
\hline 422 & 4 & & 4 & \\
\hline 423 & 2 & & & 4 \\
\hline $\begin{array}{l}\text { Average }( \pm \mathrm{SD}) \\
\text { no. of TRFs }\end{array}$ & $\begin{array}{c}10.3 \pm \\
1.7\end{array}$ & $\begin{array}{c}8.8 \pm \\
1.3\end{array}$ & $\begin{array}{c}11.5 \pm \\
1.3\end{array}$ & $\begin{array}{c}15.8 \pm \\
1.5\end{array}$ \\
\hline
\end{tabular}

\section{Antilarval settlement activity of extracts from Mycale spp.}

After $24 \mathrm{~h}$ of exposure to the filmed hydrogels, $100 \%$ survivorship was recorded for larvae of Hydroides elegans that were exposed to all different kinds of hydrogels, except those incorporated with the $\mathrm{CHCl}_{3}$ extract of Mycale adhaerens, which caused $>50 \%$ reduction in percent survivorship.

Larval settlement on the filmed hydrogels incorporated with $\mathrm{MeOH}$ and $\mathrm{CHCl}_{3}$ extracts of Mycale laxissima were $\sim 80 \%$, which was not significantly different from those on the filmed hydrogels of the $\mathrm{ddH}_{2} \mathrm{O}$ and $\mathrm{CHCl}_{3}$ controls (Mann-Whitney $U$-test; p $>0.31$; Fig. 2b). Percent larval settlement on the antibiotic control and on the filmed hydrogels treated with $\mathrm{MeOH}$ and $\mathrm{CHCl}_{3}$ extracts of $M$. adhaerens ranged from 34 to $53 \%$, which was significantly lower than that on the $\mathrm{ddH}_{2} \mathrm{O}$ and $\mathrm{CHCl}_{3}$ controls (Mann-Whitney $U$-test; $\mathrm{p}=$ 0.08). Larval settlement on the hydrogels that had their biofilms removed was not significantly different across all treatments (data not shown).

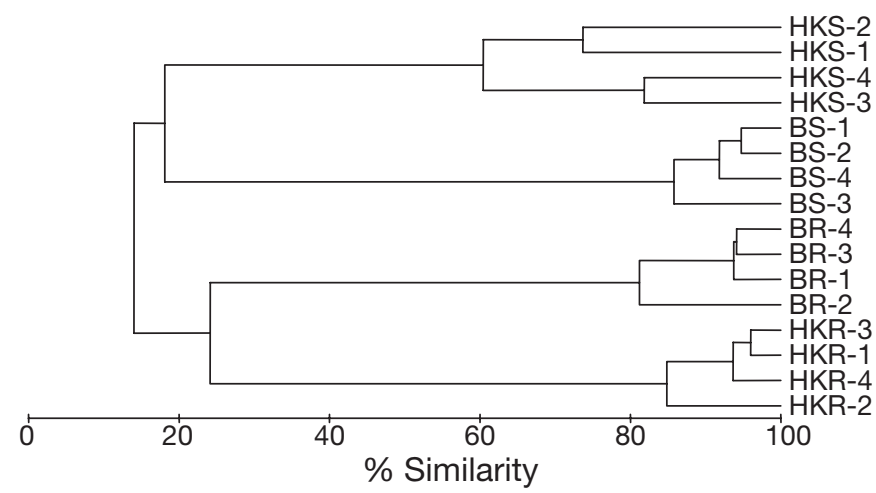

Fig. 1. Mycale spp. Dendrogram showing similarity of bacterial communities on the surfaces of 4 ind. of sponges $M$. adhaerens (HKS-1 to HKS-4) and M. laxissima (BS-1 to BS-4) in comparison with those on reference surfaces from Hong

Kong (HKR-1 to HKR-4) and the Bahamas (BR-1 to BR-4)

Table 4. Mycale spp. Antibacterial activity of extracts from M. adhaerens and M. laxissima on growth of bacteria isolated from reference and sponge surfaces. Crude extracts were obtained by combining extracts from $>1$ sponge for each species and tested at $1 \times$ tissue-level concentration. Data are number of isolates susceptible to the extracts. Numbers in parentheses: total number of bacterial isolates from that particular type of surface

\begin{tabular}{|c|c|c|c|c|}
\hline \multirow[t]{2}{*}{ Paper disc loaded with } & \multicolumn{4}{|c|}{ Test against growth of: } \\
\hline & $\begin{array}{l}\text { Hong Kong reference } \\
\text { isolates (36) }\end{array}$ & $\begin{array}{c}\text { Bahamas reference } \\
\text { isolates (24) }\end{array}$ & $\begin{array}{l}\text { M. adhaerens } \\
\text { isolates (20) }\end{array}$ & $\begin{array}{l}\text { M. laxissima } \\
\text { isolates (11) }\end{array}$ \\
\hline $50 \mu \mathrm{g}$ Streptomycin (positive control) & 34 & 21 & 18 & 10 \\
\hline $\mathrm{ddH}_{2} \mathrm{O}$ (negative control) & 0 & 0 & 0 & 0 \\
\hline $\mathrm{CHCl}_{3}$ (negative control) & 0 & 0 & 0 & 0 \\
\hline MeOH extract from $M$. adhaerens & 0 & 0 & 0 & 0 \\
\hline $\mathrm{CHCl}_{3}$ extract from $M$. adhaerens & 18 & 0 & 1 & 0 \\
\hline MeOH extract from $M$. laxissima & 7 & 0 & 0 & 0 \\
\hline $\mathrm{CHCl}_{3}$ extract from $M$. laxissima & 5 & 1 & 0 & 0 \\
\hline
\end{tabular}



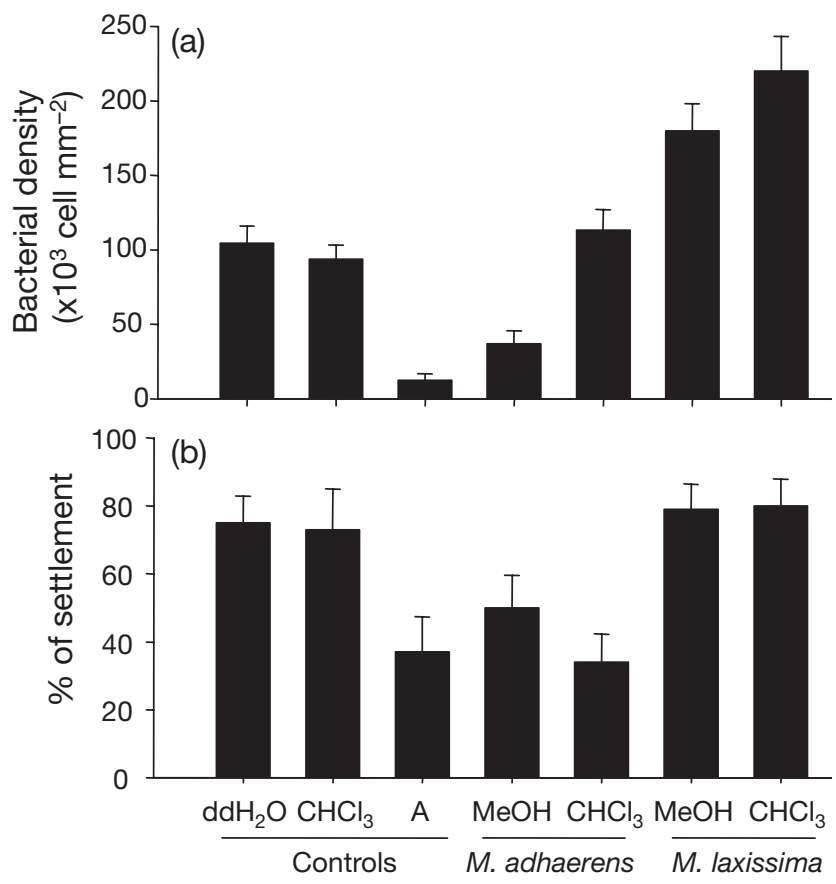

Fig. 2. Hydroides elegans, Mycale spp. (a) Bacterial density and (b) percent settlement of $H$. elegans larvae on surfaces of hydrogels with extracts from tissues of $M$. adhaerens and $M$. laxissima at $2 \times$ tissue-level concentration. Crude extracts were obtained by combining extracts from $>1$ sponge for each species. 'd $\mathrm{ddH}_{2} \mathrm{O}$ ', ' $\mathrm{CHCl}_{3}$ ' and ' $\mathrm{A}$ ' represent the 3 controls: hydrogels made with $\mathrm{ddH}_{2} \mathrm{O}$, hydrogels incorporated with $\mathrm{CHCl}_{3}$ solvent, and hydrogels incorporated with antibiotics, respectively. Hydrogels had been exposed to flow-through seawater in the natural environment for $72 \mathrm{~h}$. Data for bacterial density are mean values $(+\mathrm{SD})$ of triplicate measurements, with pseudo-replication $(\mathrm{n}=10)$ in each replicate, while data for percent larval settlement are expressed as mean $(+\mathrm{SD}$ for 5 replicates) percent of total number of larvae added to each treatment

\section{Chemical profile and fatty acid composition of extracts from Mycale spp.}

By visual comparison of chromatograms obtained from HPLC, both $\mathrm{MeOH}$ and $\mathrm{CHCl}_{3}$ extracts of $M$. adhaerens from Hong Kong and M. laxissima from the Bahamas differed in terms of number, retention time, and relative intensity of peaks (Fig. 4).

At $1 \times$ TLC, the total intensity of peaks revealed by GC-MS in the crude $\mathrm{CHCl}_{3}$ extract of Mycale laxissima was higher than that of $M$. adhaerens (Fig. 5). The 2 extracts shared 48 peaks in common, while 20 and 29 unique peaks were only observed in the extracts of M. adhaerens and M. laxissima, respectively (Fig. 5, Table 6). For example, peaks with retention times of $11.44,16.34,17.94$, and $21.06 \mathrm{~min}$ and identified as 2-hydroxy-4-hydroxylaminopyrimidine, methyl palmitate, methyl octadecanoate, and 3-methoxy-5a-morpholin-4-yl-5a, 6, 7, 8, 9, 9a-hexahydrodibenzofuran-2-ol, respectively, were found in the extracts of both sponges. On the other hand, peaks with retention times of 14.23 and $16.18 \mathrm{~min}$ and identified as 1-dodecanol, 3,7,11-trimethyl and 11-hexadecenoic acid, methyl ester, respectively, were only present in the extract of $M$. adhaerens. Similarly, peaks with retention times of 17.19, 17.48, and $18.25 \mathrm{~min}$ and identified as cyclopropanebutanoic acid, heptadecanoic acid, and octadecanoic acid, 2-hydroxy-1,3-propanediyl ester were only observed in the extract of $M$. laxissima.

Using GC-MS, 41 and 30 fatty acids were detected in the $\mathrm{CHCl}_{3}$ extracts of Mycale adhaerens and M. laxissima, respectively (Table 7 ). The most dominant fatty acid for both extracts was identified as 5,9-hexacosadienoic acid, which constituted 35.68 and $25.26 \%$ of the total fatty acids in $M$. adhaerens and M. laxissima, respectively. Although GC-MS also revealed a number of fatty acids in common for both extracts, their fatty acid profiles differed in terms of the type and relative abundance of fatty acids detected. The dominant fatty acids in the extract of $M$. adhaerens were long, straight-chain, unsaturated fatty acids, including 5,8,11,14,17-eicosapentaenoic acid, 5, 9-hexacosadienoic acid, 9,19-hexacosadienoic acid, and 19-hexacosenoic acid (together representing $51.89 \%$ of the total fatty acids), while those in the extract of $M$. laxissima were straight-chained, saturated fatty acids, including hexadecanoic acid and octadecanoic acid, and the long, straight-chained, unsaturated fatty acid 5,9-hexacosadienoic acid (together comprising $50.36 \%$ of the total) (Table 7 ). Some fatty acids were detected in 1 of the sponge extracts only. For example, $4,7,10,13,16,19$-docosahexaenoic acid and 9,10-methylene-octadecanoic acid were only found in the extracts of $M$. adhaerens and $M$. laxissima, respectively. For both extracts, branched fatty acids constituted only $<10 \%$ of the total.

\section{DISCUSSION}

Our study demonstrated that geographically separated congeneric sponges have different surfaceassociated bacterial communities and chemical and fatty acid profiles, and their extracts show different antifouling activities. In this study, we first compared the bacterial communities on the surfaces of 2 congeneric sponges, Mycale adhaerens and M. laxissima, from 2 geographically separated regions, Hong Kong and the Bahamas, respectively, using both culturedependent and -independent techniques. Despite the generally high variability of the bacterial communities associated with Mycale within one particular species (Table 2 in Lee \& Qian 2003; Fig. 1, Table 3 in the 
Table 5. Mycale spp. Terminal restriction fragments (TRF) derived from bacterial communities on surfaces of hydrogels of $\mathrm{ddH}_{2} \mathrm{O}, \mathrm{CHCl}_{3}$ solvent, and antibiotics (A), and $\mathrm{MeOH}$ or $\mathrm{CHCl}_{3}$ extracts of $M$. adhaerens and $M$. laxissima. Crude extracts were obtained by combining extracts from $>1$ sponge for each species. Hydrogels had been exposed to flow-through seawater in the natural environment for $72 \mathrm{~h}$. Data are number of occurrences of a TRF in 4 replicates of a given sample. No data: total absence of TRF in a sample

\begin{tabular}{|c|c|c|c|c|c|c|c|}
\hline \multirow{2}{*}{$\begin{array}{l}\text { Length of } \\
\text { TRF (bp) }\end{array}$} & \multirow{2}{*}{$\mathrm{ddH}_{2} \mathrm{O}$} & \multirow{2}{*}{$\mathrm{CHCl}_{3}$} & \multirow[t]{2}{*}{ A } & \multicolumn{2}{|c|}{ M. adhaerens } & \multicolumn{2}{|c|}{ M. laxissima } \\
\hline & & & & $\mathrm{MeOH}$ & $\mathrm{CHCl}_{3}$ & $\mathrm{MeOH}$ & $\mathrm{CHCl}_{3}$ \\
\hline 38 & 2 & 2 & & & & 4 & \\
\hline 39 & 4 & 2 & 3 & 2 & 3 & 2 & 3 \\
\hline 42 & & & & 3 & 3 & 2 & 2 \\
\hline 44 & & & & & & 3 & \\
\hline 45 & & & & & & 4 & \\
\hline 64 & & & & & & 3 & \\
\hline 68 & 2 & 3 & & & & 2 & 3 \\
\hline 80 & & & & 3 & & & \\
\hline 81 & & & & 3 & 2 & 4 & \\
\hline 90 & & & & & & 4 & \\
\hline 91 & 3 & 3 & & & & & \\
\hline 92,120 & & & & & & 2 & \\
\hline 123 & & & 2 & 3 & & 3 & 2 \\
\hline 125 & & & & 3 & & 2 & \\
\hline 127 & & & & 2 & 2 & 4 & \\
\hline 128 & 3 & 3 & & 3 & 3 & 4 & \\
\hline 129 & 2 & 3 & & & & & \\
\hline 149 & 2 & & & 2 & & 2 & \\
\hline 150 & & & & & & 2 & \\
\hline 151 & & & & 2 & & & \\
\hline 152,176 & & & & & & 2 & \\
\hline 177 & 3 & 2 & 3 & & & 3 & \\
\hline 182 & 2 & 2 & & & & & \\
\hline 207 & & & & & & 2 & \\
\hline 208 & & & & & & 3 & \\
\hline 281 & 2 & & & & & & \\
\hline 299 & & & & & 2 & & \\
\hline 301 & & & & 4 & 3 & & 2 \\
\hline 302 & & & & & & & 2 \\
\hline 310,311 & & & & 4 & 3 & & \\
\hline 312 & & & & & & 4 & \\
\hline 313 & 2 & 2 & 2 & 3 & & & \\
\hline 314 & 2 & 3 & & & & & \\
\hline 315 & 4 & 4 & 3 & & 2 & 3 & 4 \\
\hline 367 & 2 & 3 & & 3 & & 2 & \\
\hline 368 & 2 & 2 & & 2 & 2 & & \\
\hline 370 & 2 & 3 & & 3 & 2 & & \\
\hline 371 & & & & 2 & & 3 & \\
\hline 373 & & & & 3 & 3 & & \\
\hline 375 & 4 & 4 & 4 & 4 & 4 & 3 & 4 \\
\hline 376 & 2 & 3 & & & & 2 & \\
\hline 379 & & & & 2 & & & \\
\hline 420 & & & & & 3 & & \\
\hline 421 & & & & & 3 & & \\
\hline 422 & 4 & 4 & & 4 & & 3 & \\
\hline 423 & 3 & 2 & & & & 3 & \\
\hline 426 & & & & & 2 & & \\
\hline $\begin{array}{l}\text { Average }( \pm \\
\text { no. of TRFs }\end{array}$ & $\begin{array}{c}13.0 \pm \\
2.4\end{array}$ & $\begin{array}{c}12.5 \pm \\
1.3\end{array}$ & $\begin{array}{c}4.3 \pm \\
1.3\end{array}$ & $\begin{array}{c}16.0 \pm \\
1.2\end{array}$ & $\begin{array}{c}11.3 \pm \\
2.6\end{array}$ & $\begin{array}{c}21.0 \pm \\
1.8\end{array}$ & $\begin{array}{c}5.5 \pm \\
1.3\end{array}$ \\
\hline
\end{tabular}

present study), the sponge-associated bacterial communities were distantly related to the bacterial communities associated with the reference surfaces at their corresponding locations. Since the sponge surfaces are not 'uniform' and may consist of different micro-habitats with slightly different physical or chemical characteristics, the intraspecific variations may be attributed to the texture and topography of the sponge surfaces (Dexter et al. 1975), as well as the production of bioactive metabolites from the sponges and/ or sponge-associated microorganisms (Engel \& Pawlik 2000). Sponge metabolites may recruit specific bacteria as indicated by the unique TRFs (Table 3), which benefit the sponges indirectly, or may defend the sponges against the colonization of harmful bacteria directly. The latter was supported by the antibacterial growth (Table 4) and antibacterial attachment activities (Figs. $2 \&$ 3, Table 5) of the sponge extracts.

Using the traditional isolation procedure, more bacteria were isolated from the Hong Kong sponge than from the Bahamas sponge, and identification of these isolates by $16 \mathrm{~S}$ rRNA gene sequencing revealed no bacterium in common on either surface (Table 1). It should be kept in mind that only a small proportion $(<1 \%)$ of bacteria living in natural habitats is culturable using existing techniques (Hentschel et al. 2003). A comparison of bacterial communities based on the cultivation method can only reveal the culturable part of a community under the same selection pressure (i.e. culture conditions). Therefore, a cultureindependent technique, TRFLP analysis, which can reflect a whole bacterial population, was also employed for the comparison. Using TRFLP analysis, the bacterial community on the Hong Kong sponge derived more ribotypes (Table 3) and was found to differ substantially from that on the Bahamas sponge $(<20 \%$ similarity; Fig. 1). This observation contradicted the findings from previous studies suggesting that bacterial communities in sponges from different seas were similar (Hentschel et al. 2002, 2003), but concurred with our comparison based on the cultivation method in this study and with the findings from our laboratory on other congeneric sponge species, including Callyspongia (Qian et al. 2006) and Halichondria spp. (authors' unpubl. data). Taylor et al. (2005) also demonstrated that 


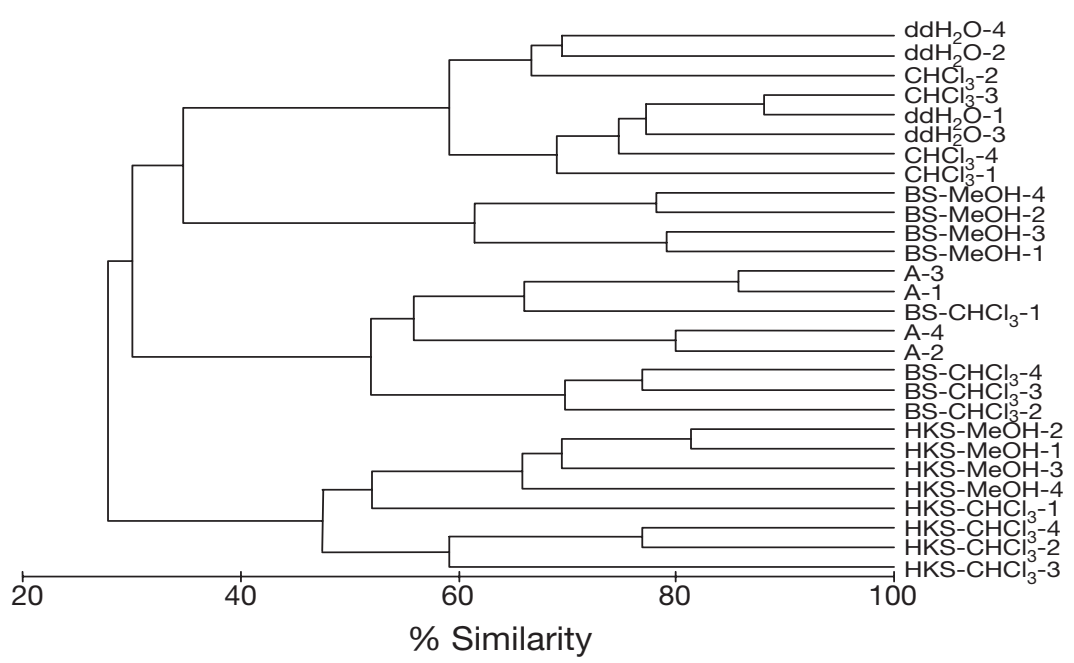

Fig. 3. Mycale spp. Dendrogram showing the similarity of bacterial communities on the surfaces of hydrogels of $\mathrm{ddH}_{2} \mathrm{O}, \mathrm{CHCl}_{3}$ solvent, antibiotics (A), and $\mathrm{MeOH}$ or $\mathrm{CHCl}_{3}$ extract of $M$. adhaerens (HKS) and of $M$. laxissima (BS). Hydrogels had been exposed to flow-through seawater in the natural environment for $72 \mathrm{~h}$

(a) $\mathrm{MeOH}$ extract of $M$. adhaerens

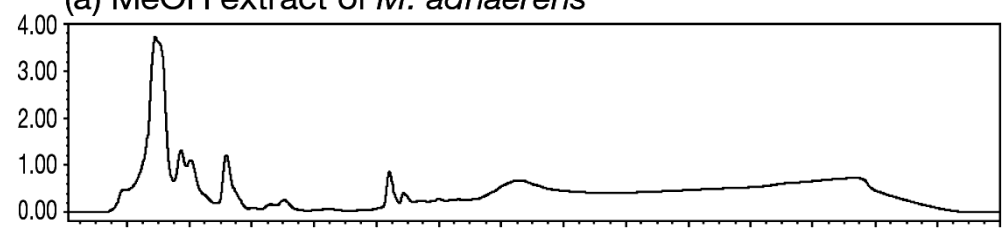

(b) $\mathrm{MeOH}$ extract of $M$. laxissima

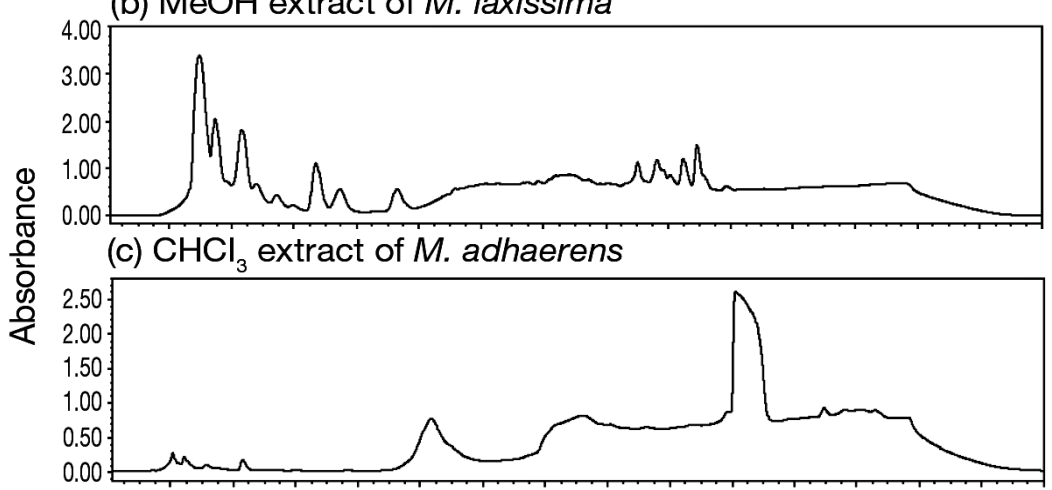

(d) $\mathrm{CHCl}_{3}$ extract of $M$. laxissima

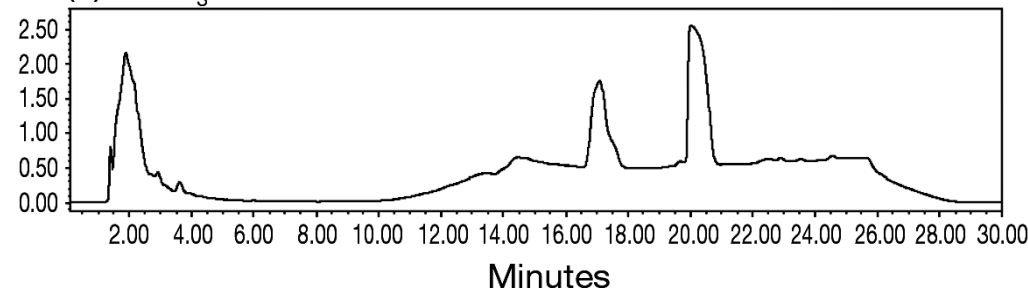

Fig. 4. Mycale spp. Chromatograms of HPLC of crude $(\mathrm{a}, \mathrm{b}) \mathrm{MeOH}$ and $(\mathrm{c}, \mathrm{d})$ $\mathrm{CHCl}_{3}$ extracts of $(\mathrm{a}, \mathrm{c}) \mathrm{M}$. adhaerens and $(\mathrm{b}, \mathrm{d}) \mathrm{M}$. laxissima. HPLC was performed using a gradient from $5 \%$ aqueous $\mathrm{CH}_{3} \mathrm{CN}$ to $85 \% \mathrm{CH}_{3} \mathrm{CN}$ at a flow rate of $1 \mathrm{ml} \mathrm{min}^{-1} ; 10 \mu \mathrm{l}$ of each extract at $20 \times$ tissue-level concentration were injected for analysis the bacterial communities associated with the sponge Cymbastela concentrica from temperate and tropical regions were different, while bacterial communities in close proximity were more similar. These discrepancies are likely due to the methods used, which target different taxonomic levels. Using TRFLP analysis, a lower taxonomic level, down to ribotypes, is revealed, while, in other studies, the comparisons are at family, class, or even phylum levels. Bacterial communities on congeneric sponges that are geographically distant may show more differences than those on sponges in close vicinity. This could be due to the simple fact that the environmental factors (e.g. temperature, nutrient content, water flow, etc.) in geographically distant areas are often different, leading to different indigenous bacterial communities in the water column that eventually colonize sponges. Although bacterioplankton differ among different oceans (Hewson et al. 2006), the effects - in respective locations - of bacterial community differences in the water column on sponge-surface bacterial communities remain unknown. Further studies using clone libraries may help identify the types of bacteria that are specifically associated with different congeneric sponges.

Sponges show heterogeneity in the distribution of different types of associated microbes and metabolites among their tissues. For instance, photosynthetically active microbes such as cyanobacteria and eukaryotic algae are generally found in the outer layer or light-exposed part of sponges, while heterotrophic and autotrophic microbes populate the inner core or the mesophyl matrix of sponges (Hentschel et al. 2003). Kubanek et al. (2002) also demonstrated that different layers of sponges contained different types and amounts of bioactive metabolites. It would be interesting to study the degree of variability in chemical profiles and antifouling activities within intraspecific sponges. However, in our study, with the aim of comparing the chemical profiles and antifouling activities of congeneric species, several 


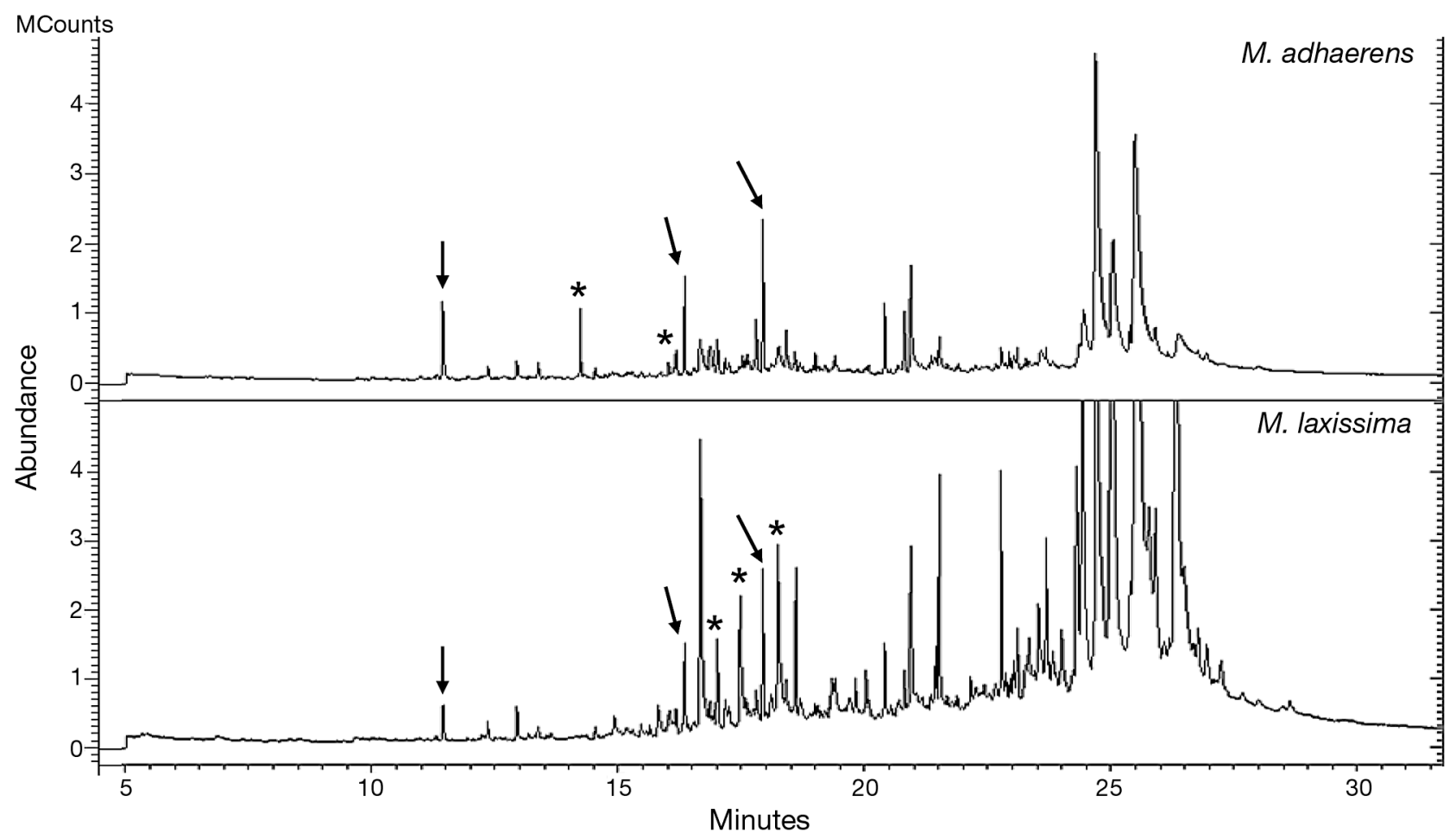

Fig. 5. Mycale spp. Chromatograms of GC-MS of crude $\mathrm{CHCl}_{3}$ extracts of $M$. adhaerens (upper panel) and $M$. laxissima (lower panel). Extracts injected were at $1 \times$ tissue-level concentration (arrows: example of common peaks; ${ }^{*}$ : examples of unique peaks present in particular extracts)

Table 6. Mycale spp. Unique peaks revealed by GC-MS in the $\mathrm{CHCl}_{3}$ extracts of $M$. adhaerens from Hong Kong (HKS) and M. laxissima from the Bahamas (BS). Crude extracts were obtained by combining extracts from $>1$ sponge for each species. $\checkmark$ : presence of a peak in a sample; no data: absence of a peak. Peaks were identified by the NIST GC-MS library and only matches with probability $>25 \%$ are presented

\begin{tabular}{|c|c|c|c|c|}
\hline $\begin{array}{l}\text { Retention } \\
\text { time (min) }\end{array}$ & $\begin{array}{l}\text { Extr } \\
\text { HKS }\end{array}$ & $\begin{array}{c}\text { act } \\
\text { BS }\end{array}$ & Closest match to the library & $\begin{array}{l}\text { Probability } \\
\quad(\%)\end{array}$ \\
\hline 10.99 & $\checkmark$ & & Benzaldehyde, 2,4,5-trimethyl- & 36 \\
\hline 18.27 & $\checkmark$ & & 2-(3-Acetoxy-4,4,10,13,14,15,16,17-tetradecahydro)-1H-cyclopenta[a]phenanthren-17 & 35 \\
\hline 18.74 & $\checkmark$ & & Hexadecanoic acid, 2-pentadecyl-1,3-dioxan-5-yl ester cis & 28 \\
\hline 20.68 & $\checkmark$ & & 2-Methoxy-5a-morpholin-4-yl-5a, 6, 7, 8, 9, 9a-hexahydrodibenzoguran-2-ol & 48 \\
\hline 23.23 & $\checkmark$ & & Cholesteryl benzoate & 29 \\
\hline 23.28 & $\checkmark$ & & 9-Desoxo-9-x-acetoxy-3,8,12-tri-O-acetylingol & 39 \\
\hline 23.87 & $\checkmark$ & & $\begin{array}{l}\text { 2-(3-Acetoxy, 4,10,13,14-pentamethyl)-2,3,4,5,6,7,10,11,12,13, 14,15,16,17- } \\
\text { tetradecahydro-1H-cyclopenta[a]phenanthren-17 }\end{array}$ & 39 \\
\hline 27.27 & $\checkmark$ & & 1',1'-Dicarboethoxy-1.beta., 2.beta.-dihydro-3H-cycloprop $[1,2]$ cholesta-1,4,6-trien-3-one & ne 33 \\
\hline 15.82 & & $\checkmark$ & Methyl 12-methyl-tridecanoate & 39 \\
\hline 17.19 & & $\checkmark$ & Cyclopropanebutanoic acid & 53 \\
\hline 18.25 & & $\checkmark$ & Octadecanoic acid, 2-hydroxy-1,3-propanediyl ester & 45 \\
\hline 19.34 & & $\checkmark$ & Docosahexaenoic acid, 1,2,3-propanetriyl ester & 48 \\
\hline 19.60 & & $\checkmark$ & Milbemycin B, 5-demethoxy-5-one-6, 28-anhydro-25-ethyl-13-chloro-oxime & 44 \\
\hline 19.83 & & $\checkmark$ & Hexanedioic acid, mono(2-ethylhexyl) ester & 60 \\
\hline 20.04 & & $\checkmark$ & Eicosanenitrile & 34 \\
\hline 20.71 & & $\checkmark$ & Indoxazen-5-ol-4-one, 3-[9-tridecenyl] & 53 \\
\hline 22.27 & & $\checkmark$ & 7,8-Epoxylanostan-11-ol, 3-acetoxy- & 47 \\
\hline 22.52 & & $\checkmark$ & Cholest-7-en-6-one, 3-(acetyloxy)-9-hydroxy-(3.beta., 5.beta.) & 26 \\
\hline 23.27 & & $\checkmark$ & 8,14-Seco-3,19-epoxyandrostane-8,14-dione,17-acetoxy-3.beta.-methoxy-4,4-dimethyl & 50 \\
\hline 23.74 & & 1 & Pagicerine & 39 \\
\hline
\end{tabular}


Table 7. Mycale spp. Fatty acid compositions of crude chloroform extracts of $M$. adhaerens from Hong Kong and M. laxissima from the Bahamas analyzed by gas chromatography-mass spectrometry (GC-MS). Crude extracts were obtained from combining extracts from $>1$ sponge for each species. $\mathrm{i}$ and $\mathrm{a}$ : isobranched and anteiso-branched fatty acids, respectively. Data presented are percent fatty acids. Fatty acids representing $<0.5 \%$ in both extracts were excluded (numbers in parentheses: positions of unsaturated bonds)

\begin{tabular}{|c|c|c|}
\hline Fatty acids & \multicolumn{2}{|c|}{ Chloroform extract of: } \\
\hline \multicolumn{3}{|l|}{ Straight chain } \\
\hline \multicolumn{3}{|l|}{ Saturated } \\
\hline Pentadecanoic acid, 15:0 & 0.19 & 2.41 \\
\hline Hexadecanoic acid, 16:0 & 4.04 & 10.88 \\
\hline Heptadecanoic acid, 17:0 & 0.30 & 1.07 \\
\hline Octadecanoic acid, 18:0 & 3.45 & 14.22 \\
\hline Nonadecanoic acid, 19:0 & 0.24 & 0.40 \\
\hline Eicosanoic acid, 20:0 & 1.54 & 0.34 \\
\hline Docosanoic acid, 22:0 & 0.93 & - \\
\hline Tetracosanoic acid, 24:0 & 1.37 & 0.44 \\
\hline \multicolumn{3}{|l|}{ Unsaturated } \\
\hline 7-Hexadecenoic acid, 16:1(7) & 1.32 & 1.59 \\
\hline $\begin{array}{l}\text { 6, 9,12,15-Hexadecatetraenoic acid, } \\
\quad 16: 4(6,9,12,15)\end{array}$ & 0.83 & 0.63 \\
\hline 7-Octadecenoic acid, 18:1(7) & 0.91 & 2.14 \\
\hline 9-Octadecenoic acid, 18:1(9) & 1.61 & 2.97 \\
\hline $5,8,11,14$-Eicosatetraenoic acid, $20: 4(5,8,11,14)$ & 1.99 & 2.67 \\
\hline $\begin{array}{l}\text { 5, 8,11,14,17-Eicosapentaenoic acid, } \\
20: 5(5,8,11,14,17)\end{array}$ & 5.66 & 1.31 \\
\hline 9-Eicosenoic acid, 20:1(9) & 1.01 & 1.65 \\
\hline 5,13-Docosadienoic acid, 22:2(5,13) & 0.80 & 2.99 \\
\hline $\begin{array}{l}4,7,10,13,16 \text {-Docosapentaenoic acid, } \\
22: 5(4,7,10,13,16)\end{array}$ & 0.56 & - \\
\hline $\begin{array}{l}4,7,10,13,16,19-\text { Docosahexaenoic acid, } \\
22: 6(4,7,10,13,16,19)\end{array}$ & 3.77 & - \\
\hline 5,9-Tricosadienoic acid, 23:2(5,9) & 0.71 & 1.82 \\
\hline 9-Tetracosaenoic acid, 24:1(9) & 3.21 & 0.59 \\
\hline 15-Tetracosaenoic acid, 24:1(15) & 0.81 & 1.12 \\
\hline 5,9-Pentacosadienoic acid, 25:2(5,9) & 3.10 & 1.44 \\
\hline 19-Hexacosenoic acid, 26:1(19) & 4.96 & 0.71 \\
\hline 5,9-Hexacosadienoic acid, 26:2(5,9) & 35.68 & 25.26 \\
\hline 9,19-Hexacosadienoic acid, $26: 2(9,19)$ & 5.59 & 2.55 \\
\hline $5,9,19$-Hexacosatrienoic acid, $26: 3(5,9,19)$ & 0.73 & - \\
\hline \multicolumn{3}{|l|}{ Branched } \\
\hline \multicolumn{3}{|l|}{ Saturated } \\
\hline 12-Methyl-tridecanoic acid, i14:0 & 0.80 & 1.93 \\
\hline 13-Methyl-tetradecanoic acid, i15:0 & 0.16 & 0.72 \\
\hline 14-Methyl-pentadecanoic acid, i16:0 & 0.28 & 0.30 \\
\hline 14-Methyl-heptadecanoic acid, a17:0 & 0.46 & 0.31 \\
\hline 15-Methyl-heptadecanoic acid, i17:0 & 0.40 & 0.20 \\
\hline 3-Methoxy-heptadecanoic acid, 3-methoxy 17:0 & 0.55 & - \\
\hline 16-Methyl-octadecanoic acid, a19:0 & 0.13 & 0.89 \\
\hline \multicolumn{3}{|l|}{ Unsaturated } \\
\hline 3-Methoxy-docosadienoic acid, 3-methoxy 20:2 & 4.22 & 0.58 \\
\hline \multicolumn{3}{|l|}{ Cyclic } \\
\hline $\begin{array}{l}\text { 9,10-Methylene-octadecanoic acid, } \\
\text { 19:0 cyclo w9c }\end{array}$ & - & 2.26 \\
\hline
\end{tabular}

colonies from each species were combined, extracted, and analyzed in order to minimize bias introduced based on the comparisons of 1 sponge colony from each species.
The crude extracts from the 2 sponges were tested for antibacterial activity against bacterial isolates from the reference and sponge surfaces. Disc diffusion assays revealed that the $\mathrm{CHCl}_{3}$ extract from the Hong Kong sponge inhibited the growth of half of the bacteria isolated from the reference surface from Hong Kong, but not any of those isolated from the Bahamas reference surface (Table 4). Similarly, Newbold et al. (1999) demonstrated that different sponges from the Caribbean produced different antibacterial compounds that targeted different bacterial strains. Kelman et al. (2001) also reported that extracts from sponges only affected the growth of indigenous bacteria isolated from the water column, but not the growth of spongeassociated bacteria. Besides, the extracts were embedded in phytagels at TLC and tested for anti-bacterial attachment activity. It should be noted that this concentration may not exactly be the concentration that naturally occurred in the sponge tissues, since the distribution of compounds in the sponges was unknown in the present study. However, assuming that compounds are distributed evenly throughout the tissue volume, it is likely an ecologically meaningful concentration, and is a widely accepted measurement for ecological studies (Jensen et al. 1996). In the phytagel assays, certain bacterial types, as indicated by specific TRFs, were excluded from the surfaces of hydrogels containing extracts of different sponges (Table 5). All of the sponge extracts altered the bacterial communities on hydrogel surfaces to certain extents (Fig. 3). These results indicate that the 2 congeneric Mycale spp. possess anti-microfouling activity, which functions by inhibiting bacterial growth or attachment. The activity is specific to ecologically relevant bacteria, which may explain the differences in bacterial communities associated with the surfaces of the 2 sponges. Larvae of an important fouling polychaete Hydroides elegans in Hong Kong waters responded differently to the hydrogels containing extracts of different sponges (Fig. 2b). This polychaete exists in the same habitat as 
Mycale adhaerens, but fouling by this species has not been observed on the sponge surface. An indirect chemical defense mechanism against larval settlement, via modulating the surface bacterial community of the sponge, was thus proposed. To test this hypothesis, the filmed hydrogels were subsequently exposed to the larvae. Hydrogels with bacterial films altered by the $\mathrm{CHCl}_{3}$ and $\mathrm{MeOH}$ extracts from Hong Kong sponge, not only killed the larvae, but also inhibited larval settlement, while those with bacterial films altered by extracts from the Bahamas sponge did not. The anti-larval settlement effect of the Hong Kong sponge extracts may be attributed to the extracts themselves or to the bacterial films altered by these extracts. However, the former is unlikely because none of the larvae were killed, nor was larval settlement inhibited when the bacterial films on the hydrogels were removed (data not shown). In fact, larvae of $H$. elegans respond differently to different mono-species bacterial films (Lee \& Qian 2003) and were sensitive to the bacterial species composition and the bacterial density of the films (Huang \& Hadfield 2003). Therefore, the extracts from the Hong Kong sponge likely alter the bacterial communities by changing bacterial species composition and/or bacterial density on hydrogel surfaces, which, in turn, controls larval settlement of $H$. elegans; an indirect defense mechanism against fouling by $H$. elegans is thus proposed. Again, these results support our assertion that the bioactivity of sponge extracts is species specific. It would be equally interesting if a major fouling organism in the Bahamas could also be included in the bioassays, which could provide a more comprehensive assessment of the antifouling activity of extracts against ecologically relevant organisms.

In order to correlate the observed differences in surface bacterial communities and antifouling activities to the chemical compositions of the 2 congeneric sponges, the sponge tissue extracts were subjected to HPLC and GC-MS analyses. Our results indicate that the chemical compositions of the crude extracts from the 2 sponges differ, evidenced by different peak patterns in HPLC and GC-MS chromatograms (Figs. 4 \& 5, Table 6). In addition, fatty acid profiles for the extracts of the 2 Mycale sponges differed and the Hong Kong sponge had a more diverse fatty acid composition (Table 7). The dominant fatty acid for both sponges was 5,9-hexacosadienoic acid, which is a major fatty acid in Demospongia (Ando et al. 1998). Surprisingly, there has been no report on bioactivity of this fatty acid. Other monosaturated fatty acids, including 7-hexadecenoic acid, 7-octadecenoic acid, and 9octadeceonic acid, were found in both sponges. As these fatty acids are typical fatty acids of cyanobacteria, fungi, and microalgae (Harwood \& Russell
1984), they are possibly of microbial origin in both sponges. Some fatty acids, for instance, the polyunsaturated fatty acids 5,8,11,14,17-eicosapentaenoic acid, 4,7,10,13,16,19-docosahexaenoic acid, and $4,7,10,13,16$-docosapentaenoic acid and the branched fatty acids 3-methoxy-heptadecanoic acid, 17-methyloctadecanoic acid, 13-methyl-eicosanoic, and 3-methoxy-docosadienoic acid, were found or were highly abundant only in the Hong Kong sponge (Table 7). The long-chained polysaturated fatty acids and the branched fatty acids are characteristic of microalgae and bacteria, respectively (Harwood \& Russell 1984), suggesting possible involvement of associated microbes of the Hong Kong sponge in the production of these fatty acids. The polyunsaturated fatty acids 5,8,11,14,17-eicosapentaenoic acid and 4,7,10,13,16,19 -docosahexaenoic acid were reported to be toxic to an anostracan grazer (Jüttner 2001) and to ameliorate murine acute renal failure (Kielar et al. 2003), respectively, but unfortunately there has been no reference in the literature to the other specific polysaturated and branched fatty acids. On the other hand, the Bahamas sponge had a higher proportion of saturated fatty acids (35.7 vs. $16.7 \%$ ), dominated by hexadecanoic acid and octadecanoic acid, but a much lower proportion of unsaturated fatty acids (48.4 vs. 77.2\%) than the Hong Kong sponge (Table 7). In addition, a cyclic fatty acid, 9,10-methylene-octadecanoic acid, was detected only in the Bahamas sponge. Again, we know relatively little about the bioactivity of these fatty acids. At present, there is only 1 study that has reported on the fatty acids isolated from a Mycale sp. (Carballeira et al. 1992), but bioactivity of the fatty acids was not measured.

The present study has demonstrated that the bacterial communities on the surfaces of 2 congeneric Mycale sponges, one from Hong Kong and the other from the Bahamas, differed substantially, and the 2 sponges showed different bioactivities in inhibiting bacterial colonization and the larval settlement of Hydroides elegans. These differences may simply be due to the geographical separation of the 2 sponges. However, the differences in the production of bioactive metabolites, particularly the fatty acid composition, as shown by different chemical compositions of the crude extracts of the 2 sponges, may also contribute to the differences in the surface bacterial communities. In reverse, the differences in the surface bacterial communities may result in the differences in chemical compositions, since different associated bacteria would produce different metabolites or fatty acids with different functions, resulting in different sponge bioactivities. Our results also suggest the possible involvement of associated microbes in the production of fatty acids in sponges; therefore, isolation of associated microbes 
and analysis of their fatty acid profiles might help verify this hypothesis. Furthermore, future investigations involving the isolation and testing of purified active compounds and fatty acids from these sponges may help us understand the complex interactions between bioactive compound production, surface bacterial community structure, and the antifouling activity of sponges.

Acknowledgements. We thank Ms. Y. K. Tam (Hong Kong) for assistance in molecular bacterial community fingerprinting analysis, Mr. J. D. Cowart (USA) for assistance in chemical extraction of sponge tissues, Mrs. Y. Plakhotnikova (Hong Kong) for assistance in bacterial isolation and identification, Prof. R. van Soest (Netherlands) for the identification of the sponges, and Dr. V. Thiyagarajan for his useful comments. We are also grateful to the captain and crew of the RV 'Seward Johnson I', and to the Government of the Bahamas for allowing us to conduct scientific research in their territorial waters. The present study was supported by Hong Kong RGC grants (HKUST 6240/04M, CAG04/05.SC01) to P.Y.Q. and by the US National Science Foundation Biological Oceanography Program to J.R.P. (OCE-0095724).

\section{LITERATURE CITED}

Amsler CH, Moeller CB, McClintock JB, Iken KB, Baker BJ (2000) Chemical defenses against diatom fouling in Antarctic marine sponges. Biofouling 16:29-45

Ando Y, Kawabata Y, Narukawa K, Ota T (1998) Demospongic acids of the marine sponge Halichondria panicea from the coast of Hokkaido, Japan. Fish Sci 64:136-139

Becerro MA, Thacker RW, Turon X, Uriz MJ, Paul V (2003) Biogeography of sponge chemical ecology: comparisons of tropical and temperate defenses. Oecologia 135:91-101

Carbelleira NM, Negrón V, Reyes ED (1992) Novel monounsaturated fatty acids from the sponges Amphimedon compressa and Mycale laevis. J Nat Prod 55:333-339

Carballeira NM, Betancourt JE, Orellano EA, González FA (2002) Total synthesis and biological evaluation of (5Z,9Z)-5, 9-hexadecadienoic acid, an inhibitor of human topoisomerase I. J Nat Prod 65:1715-1718

Carreau JP, Dubacq JP (1978) Adaptation of macro-scale method to the micro-scale for fatty acid methyl transesterification of biological lipid extracts. J Chromatogr 151: 384-390

Clarke KR, Warwick RM (1994) Change in marine communities: an approach to statistical analysis and interpretation. Plymouth Marine Laboratory, Plymouth

Dexter SC, Sullivan JD Jr, Williams J III, Watson SW (1975) Influence of substrate wettability on the attachment of marine bacteria to various surfaces. Appl Microbiol 30: 298-308

Duchassaing de FP, Michelotti G (1864) Spongiaires de la mer Caraïbe. Nat Verh Holl Maatsch Wetensch Haarlem (2)21: $1-124$

Engel S, Pawlik JR (2000) Allelopathic activities of sponge extracts. Mar Ecol Prog Ser 207:273-281

Freitas JC, Rangel M, Oliveira JS, Zaharenko AJ, Rozas E (2003) An outline of marine toxinology studies in the Brazilian coast. Comments Toxicol 9:137-159

Furrow FB, Amsler CD, McClintock JB, Baker BJ (2003) Surface sequestration of chemical feeding deterrents in the Antarctic sponge Latrunculia apicalis as an optimal defense against sea star spongivory. Mar Biol 143:443-449

Fusetani N, Tamura K, Matsunaga S, Hirota H (1991) Cytotoxic metabolites of the marine sponge Mycale adhaerens Lambe. J Org Chem 56:4971-4974

Fusetani N, Li HY, Tamura K, Matsunaga S (1993) Antifungal brominated $\mathrm{C}_{18}$ acetylenic acids from the marine sponge, Petrosia volcano Hoshino. Tetrahedron 49:1203-1210

Gillian FT, Stoilov IL, Thompson JE, Hogg RW, Wilkinson CR, Djerassi C (1988) Fatty acids as biological markers for bacterial symbionts in sponges. Lipids 23(12):1139-1145

Gray JE (1867) Notes on the arrangement of sponges, with the description of some new genera. Proc Zool Soc Lond 1867:492-558

Harder T, Lau SCK, Tam WY, Qian PY (2004) A bacterial culture-independent method to investigate chemicallymediated control of bacterial epibiosis in marine invertebrates by using TRFLP analysis and natural bacterial populations. FEMS Microb Ecol 47:93-99

Harwood JL, Russell NJ (1984) Lipids in plants and microbes. Allen \& Unwin, London

Hentschel U, Schmid M, Wanger M, Fieseler L, Gernert C, Hacker J (2001) Isolation and phylogenetic analysis of bacteria with antimicrobial activities from the Mediterranean sponges Aplysina aerophoba and Aplysina cavernicola. FEMS Microb Ecol 35:305-312

Hentschel U, Hopke J, Horn M, Friedrich A, Wagner M, Hacker J, Moore B (2002) Molecular evidence for a uniform microbial community in sponges from different oceans. Appl Environ Microbiol 68:4431-4440

Hentschel U, Fieseler L, Wehrl M, Gernert C, Steinert M, Hacker J, Horn M (2003) Microbial diversity of marine sponges. In: Müller WEG (ed) Marine molecular biotechnology. Springer-Verlag, Berlin, p 59-88

Hewson I, Steele JA, Capone DG, Fuhrman JA (2006) Temporal and spatial scales of variation in bacterioplankton assemblages of oligotrophic surface waters. Mar Ecol Prog Ser 311:67-77

Huang S, Hadfield MG (2003) Composition and density of bacterial biofilms determine larval settlement of the polychaete Hydroides elegans. Mar Ecol Prog Ser 260:161-172

Jesen PR, Harvell CD, Wirtz K, Fenical W (1996) Antimicrobial activity of extracts of Caribbean gorgonian corals. Mar Biol 125:411-419

Jüttner F (2001) Liberation of 5,8,11,14,17-eicosapentaenoic acid and other polyunsaturated fatty acids from lipids as a grazer defense reaction in epilithic diatom biofilms. J Phycol 37:744-755

Kelman D, Kashman Y, Rosenberg E, Ilan M, Ifrach I, Loya Y (2001) Antimicrobial activity of the reef sponge Amphimedon viridis from the Red Sea: evidence for selective toxicity. Aquat Microb Ecol 24:9-16

Kielar ML, Jeyarajah DR, Zhou XJ, Lu CY (2003) Docosahexaenoic acid ameliorates murine ischemic acute renal failure and prevents increases in mRNA abundance for both TNF-alpha and inducible nitric oxide synthase. J Am Soc Nephrol 14(2):389-396

Kon-ya N, Shimidzu N, Otaki N, Yokoyama A, Adachi K, Miki W (1995) Inhibitory effect of bacterial ubiquinones on the settling of barnacle, Balanus amphitrite. Experientia 51: 153-155

Kubanek J, Whalen KE, Engel S, Kelly SR, Henkel TP, Fenical W, Pawlik JR (2002) Multiple defensive roles for triterpene glycosides from two Caribbean sponges. Oecologia 131: $125-136$

Lafi FF, Garson MJ, Fuerst JA (2005) Culturable bacterial symbionts isolated from two distinct sponge species (Pseudoceratina clavata and Rhabdastrella globostellata) 
from the Great Barrier Reef display similar phylogenetic diversity. Microb Ecol 50:213-220

Lambe LM (1893) On some sponges from the Pacific Coast of Canada and Bering Sea. Trans R Soc Can 10:67-78, pl III-VI

Lee OO, Qian PY (2003) Chemical control of bacterial epibiosis and larval settlement of Hydroides elegans in the red sponge Mycale adhaerens. Biofouling 19(Suppl): $171-180$

Lee OO, Qian PY (2004) Potential control of bacterial epibiosis on the surface of the sponge Mycale adhaerens. Aquat Microb Ecol 34:11-21

Lee OO, Lau SCK, Qian PY (2006) Consistent bacterial community structure associated with the surface of the sponge Mycale adhaerens. Microb Ecol 52:693-707

Liu WT, Marsh TL, Cheng H, Forney LJ (1997) Characterization of microbial diversity by determining terminal restriction fragment length polymorphisms of genes encoding 16S rRNA. Appl Environ Microbiol 63(11):4516-4522

Maldonado M, Cortadellas N, Trillas MI, Rützler K (2005) Endosymbiotic yeast maternally transmitted in a marine sponge. Biol Bull (Woods Hole) 209:94-106

Margot H, Acebal C, Toril E, Amils R, Fernandez Puentes JL (2002) Consistent association of crenarchaeal Archaea with sponges of the genus Axinella. Mar Biol 140(4):739-745

McClintock JB, Baker BJ (1997) A review of the chemical ecology of Antarctic marine invertebrates. Am Zool 37:329-342

McClintock JB, Baker BJ (2001) Marine chemical ecology. CRC Press, Boca Raton, FL

Newbold RW, Jensen PR, Fenical W, Pawlik JR (1999) Antimicrobial activity of Caribbean sponge extracts. Aquat Microb Ecol 19:279-284

Editorial responsibility: Howard Browman (Associate Editorin-Chief), Storebø, Norway
Qian PY, Dobretsov S, Dahms HU, Pawlik JR (2006) Antifouling activities and microbial diversity of two congeneric sponge Callyspongia spp. from Hong Kong and the Bahamas. Mar Ecol Prog Ser 324:151-165

Paul VJ, Puglisi MP, Ritson-Williams R (2006) Marine chemical ecology. Nat Prod Rep 23:153-180

Rangel M, de Sanctis B, de Freitas JC, Polatto JM, Granato AC, Berlinck RGS, Hajdu E (2001) Cytotoxic and neurotoxic activities in extracts of marine sponges (Porifera) from southeastern Brazilian coast. J Exp Mar Biol Ecol 262(1):31-40

Rod'kina SA (2005) Fatty acids from the sponge Tedania dirhaphis. Chem Nat Comp 41(3):289-292

Tachibana Y, Scheuer PJ, Tsukitani Y, Kikuchi H, Van Engen D, Clardy J, Gopichand Y, Schmitz FJ (1981) Okadaic acid, a cytotoxic polyether from two marine sponges of the genus Halichondria. J Am Chem Soc 103:2469-2471

Taylor MW, Schupp PJ, de Nys R, Kjelleberg S, Steinberg PD (2005) Biogeography of bacteria associated with the marine sponge Cymbastela concertrica. Environ Microbiol $7: 419-493$

Thacker RW, Starnes S (2003) Host specificity of the symbiotic cyanobacterium Oscillatoria spongeliae in marine sponge, Dysides spp. Mar Biol 142:643-648

Thakur NL, Anil AC, Muller WEG (2004) Culturable epibacteria of the marine sponge Ircinia fusca: temporal variations and their possible role in the epibacterial defense of the host. Aquat Microb Ecol 37(3):295-304

Tsukamoto S, Matsunaga S, Fusetani N, Van Soest RWM (1998) Acanthosterol sulfates A-J: ten new antifungal steroidal sulfates from a marine sponge Acanthodendrilla sp. J Nat Prod 61:1374-1378

Submitted: May 5, 2006; Accepted: November 19, 2006 Proofs received from author(s): May 10, 2007 